\title{
Supervision and Control of Local Governance in the Republic of Kosovo
}

\author{
Msc. Mervete Shala PhD Cand. \\ Lecturer, University Haxhi Zeka Peja Kosovo \\ mervete.shala@unhz.eu
}

Msc. Skender Shala

Former Senior Official for monitoring and Municipal Transparency in

Ministry of Administration of Local Government of Kosovo

skendershala@live.com

\begin{abstract}
In this paper we have treated supervision and control of local governance in context of fair governance in Republic of Kosovo. Analyse of law framework and European standards of governance autonomy of local self-governance and administrative supervision of local governance. Treating of supervision of local authority governance and the main mechanism of government for legal administrative review of local authority governance and legality as well as the rights of the supervising authority for administrative review of legality of general acts of municipalities. The purpose of this paper is to analyse and tackle the challenges of supervision and control of local government institutions in Kosovo. The mandate and powers of the central government to review the legality of local authorities in the field of enhanced competencies and the legality and appropriateness of their scope of activities of in the field of delegated powers. The challenges of preserving the autonomy of local self-government and local government supervision by the central authorities. One of the challenges of the supervisor in the future will be to supervise and control of municipalities with extended competences (municipalities with Serb majority), shall these municipalities consider requirements to be review the unlawful acts and harmonize them with the applicable legislation in Kosovo. The methodology of the paper will be mixed, such as: as comparative methods, descriptive, requesting explanatory, predictive.
\end{abstract}

Keywords: local governance, autonomy, supervision, control, good governance

\section{Introduction}

Kosovo after war in year 1999 was ruled under the Administration of the United Nations.

Resolution 1244 (1999) adopted by the Security Council at its 4011th meeting, on 10 June 1999 decides that the main responsibilities of the international civil presence will include: organizing and overseeing the development of provisional institutions for democratic and autonomous self-government pending a political settlement, including the holding of elections. Transferring, as these institutions are established, its administrative responsibilities while overseeing and supporting the consolidation of Kosovo's local provisional institutions and other peace-building activities.In a final stage, overseeing the transfer of authority from Kosovo's provisional institutions to institutions established under a political settlement (Resolution 1244 (1999) article 11).All legislative and executive authority with respect to Kosovo, including the administration of the judiciary, is vested in UNMIK and is exercised by the Special Representative of the Secretary-General. The Special Representative of the Secretary-General may appoint any person

to perform functions in the civil administration in Kosovo, including the judiciary, or remove such person.(Regulation No. 1999/1 UNMIK Section 1).The Special Representative of the Secretary-General shall appoint, and may transfer or replace, a Regional Administrator for each of the five regions of Kosovo (Pristina, Pec, Mitrovica, Prizren and Gnjlane) to act on his behalf. The Regional Administrators shall report to the Deputy Special Representative of the Secretary-General for Civil 
Administration. The Regional Administrators shall control, discharge or otherwise supervise the functions entrusted to public services and local government bodies in the

respective regions and may require that those services or bodies seek his or her prior approval for specific decisions or initiatives.(Regulation No. 1999/14 UNMIK Sections 1and 2).Authority to administer public, state and socially-owned property in accordance with the relevant UNMIK legislation in force, in cooperation with the Provisional Institutions of Self Government. (Regulation No. 2001/9 Chapter 8 drops q). The activity of local self-government bodies is based on this Constitution and the laws of the Republic of Kosovo and respects the European Charter of Local Self-Government.( Constitution Article 123).In the Republic of Kosovo the basic unit of local government is the municipality. Municipalities enjoy a high degree of local self-governance and encourage and ensure the active participation of all citizens in the decision-making process of the municipal bodies. Municipalities have their own, extended and delegated competencies in accordance with the law. The state authority which delegates competencies shall cover the expenditures incurred for the exercise of delegation. Municipalities have the right to decide, collect and spend municipal revenues and receive appropriate funding from the central government in accordance with the law. Municipalities are bound to respect the Constitution and laws and to apply court decisions. The administrative review of acts of municipalities by the central authorities in the area of their own competencies shall be limited to ensuring compatibility with the Constitution of the Republic of Kosovo and the law.(Constitution Article 124).

The main purpose of this paper is to examine the role and influence of the supervision and control of local government to ensure professional, effective, efficient, accountable, transparent and accountability of local government in local level, which shall be be at the service of municipal citizens.

The structure of the paper includes the supervision, control and types of supervision and control of municipalities, including the supervision and internal control. Also, legal supervisory authority of municipalities and review of the legality of acts of Municipalities of Kosovo and in the end we have presented the conclusions.

We have supported the methodology of research based on primary and secondary sources, analysis of all legal frameworks on which relies the supervision and control of local government in Kosovo and the literature of various authors and reports of the Ministry of Local Administration

\section{Meaning of the Supervision and Control of local government}

Related to control of administration says $\mathrm{H}$. Fayoll said that the control is the verification, if the works are carried out with the approved plan, given command and certain principles (Sokoli, 2009, p.11). The purpose of the control exercising and undertaking of measures to ensure the legality, in the first place to make the violated law function properly and secondly to specify the accuracy of the authorities or employees of public apparatus that have violated or have allowed violation of the law.(Dobajni,2004,p.19). The purpose of control is to make impossible the determination, namely the application of that general normative legal act that would oppose the constitution or the law. As a result, even with sanctions, as stipulated with special legal systems, tends to avoid from the legal system those general bylaws normative legislation acts that are not in accordance with provisions with the principles expressed in the Constitution, respectivlley, laws.(Polozhani, Dobjani,Stavileci, \& Salihu,2010, p. 49). Since 1999, when Kosovo was placed under international protectorate, it was confronted and was challenged by multiple transitions, three of which were main for the socio economic development and good governance in the country, as: the transformation from the authoritarian political system into that democratic; the transition from a state planned economy to the market economy and the transfer of powers from the UNMIK temporary structures to the independent institutions of Kosovo.(MLGA Organization and functioning of Local Self-Government in Kosovo, 2013, p. 5)

The activity of local self-government bodies is based on this Constitution and the laws of the Republic of Kosovo and respects the European Charter of Local Self-Government. The Republic of Kosovo shall observe and implement the European Charter on Local Self Government to the same extent as that required of a signatory state. Local selfgovernment is based upon the principles of fair governance transparency, efficiency and effectiveness in providing public services having due regard for the specific needs and interests of the Communities not in the majority and their members. ( Constitution of the Republic of Kosovo article 132).Also, article 124 of Constitution of the Republic of Kosovo provides that Municipalities enjoy a high degree of local self-governance and encourage anad ensure the active 
participation of all citizens in the decision-making process of the municipal bodies.(Constitution of Kosovo article 124). Our control system is oriented more in supervision than in control. In the Republic of Kosova, the monitoring system of local government is regulated by the Constitution, Law on local self-government as well as other sectorial laws. This system is more limited in the possibility of the consulting intervention and recommendation, in case of exercising the competencies of the bodies of local self-government and is built as part of relationship between the central and that local level.(MLGA Organization and functioning of Local Self-Government in Kosova,2013,p.51 ).The the European Charter of Local Self-Government commits the ratifying member states to guaranteeing the political, administrative and financial independence of local authorities.(Council of Europe Charte européenne de l'autonomie locale et rapport explicative, 1986).

The administrative and territorial organisation of the Republic of Kosovo is currently comprised of 38 municipalities, respectively 27 Albanian-majority municipalities, 1 Turkish-majority municipality and 10 Serb- majority municipalities.(MLGA Municipal performance Report 2014 p.11).Local self-government is an autonomous system of governance, through which, their political governance, legal, financial and administrative, were attributed to them. This system promotes democratic behaviour, transparency and accountability as well as ensures a mutual system of control at the municipal level to prevent illegal actions. Thus, municipalities are obliged to exercise the activity under the Constitution, laws, norms issued by them, the norms which can have the same impact as the state norms, although dependent on these latter.(MLGA Organization and functioning of Local Self-Government in Kosovo, 2013, p 52). Municipalities are subject to supervision of the legality of their activities with regard to performance of own and extended responsibilities. Insofar supervision is carried out according to the Law on Local Self Government. Municipalities carrying out tasks delegated by the state administration are subject to supervision of the legality and of the expediency including effectiveness and efficiency of their delegated activities. (Law No.03/L -189 articles 65$)$.

\subsection{Types of supervision and control of Municipalities}

Constitution of the Republic of Kosovo article 124 provide that Municipalities have their own, extended and delegated competencies in accordance with the law. The state authority which delegates competencies shall cover the expenditures incurred for the exercise of delegation. Municipalities have the right of inter-municipal cooperation and cross-border cooperation in accordance with the law. Municipalities have the right to decide, collect and spend municipal revenues and receive appropriate funding from the central government in accordance with the law. Referring to article 124 paragraph 6 to the Constitution provides that Municipalities are bound to respect the Constitution and laws and to apply court decisions. The administrative review of acts of municipalities by the central authorities in the area of their own competencies shall be limited to ensuring compatibility with the Constitution of the Republic of Kosovo and the law.(The Constitution of Kosovo article 124).

Monitoring and supervision of municipalities is the right of the Ministry of Local Government to monitor and supervise the implementation of the responsibilities of municipal bodies ensuring that municipal acts are in full compliance with applicable legislation, the municipality framework of Kosovo competencies.(Administrative Instruction No. 2008/4 article 2 ).Kosovo has strengthened its cooperation between the central and local level. Ministry of Local Government has made an advancement with monitoring system and assistance to municipal authorities.(MLGA Organization and functioning of Local Self-Government in Kosovo, 2013,p.4). However, despite the individuality of the municipalities in carrying out of their activities, legislation has established a degree of dependence in relation to the central authorities. In this context, determination by law of the supervisory nature function of Ministry of Local Government Administration and other line Ministries towards municipalities is particularly important as it enables partial restriction of the municipality activities. This coincides with control of law respecting as determined by law and established only for relevant public reasons.(MLGA Monitoring report of the Republic of Kosovo Municipalities January-December 2012,p.3).

Comprehension of supervision and control of the municipalities in Kosovo is determined in two fields:

- Internal control; and

- External control

Within the supervision, should be mentioned also the social supervision, which is realized through various forms of the direct democracy. 


\subsection{Supervision and the Internal Control}

Supervision and Internal Control in the municipality means the right of municipality bodies legally authorized, for provision of respect of the legality and constitutionality by the lowest level bodies within the municipality. Taking into account the structural separation the Assembly / Executive within the municipality, there also exist responsibilities for controlling the work of these bodies, taking into consideration their field of activity. The legal framework has set possibilities of municipal bodies control in two ways:

- $\quad$ control that the Municipal Assembly performs towards the Executive and

- $\quad$ control made by mayor of municipality in relation to municipal directorates

\subsubsection{Control of the Assembly on the Executive of the municipality}

Although in terms of control, are not foreseen specific provisions which regulate the manner of control (AssemblyExecutive), this issue can be understood on the basis of the hierarchy established by law according to the Law on Local Self-Government, the Assembly of municipality is defined to be the highest body in the municipality and at the same time the supervisory organ at the local level, competent for ensuring the provision of services by the executive in accordance with the legislation in force.( MLGA Organization and functioning of Local Self-Government in Kosova,2013 pp 52 and ,53). Law No on Local Self Government article 35 Municipal Assembly is the highest representative body of the municipality and shall be directly elected by the citizens in accordance with the Law on Local Elections. (Law No. 03/L-040 article 35). Municipal Assembly, hold meeting regular, Extraordinary Meetings how and Open Meetings to the public.(Law No. 03/L040 Arts 43, 44, and article 45). The Municipal Assembly is the highest body of the Municipality which exercises the function of local government, as defined by the Law on Local Self-Government and the Statute of the Municipality. Responsibilities and Municipal powers have to be exercised by the Municipal Assembly and the Mayor, unless otherwise provided by the Law on Local Self-Government and other laws and Municipal Statute.(Municipal Statute of Pristina Article 29). The Municipal Assembly is the highest representative body of local government and at the same time legally authorized supervisory body for provision of services by the municipal executive in accordance with the legislation in force. To exercise its function, the Municipal Assembly should meet regularly in order to carry out responsibilities within the municipal powers, to adopt the necessary the normative acts for functioning of the municipality, the acts explicitly required by the applicable legislation or which laws are those that are left open to to activate them depending on the needs of municipalities and to discuss and decide upon the matters of interest for the municipality.( MLGA Report on Functioning of the Municipal Assemblies of the Republic of Kosovo, 2013, p.10)

The Mayor represents and acts on behalf of the Municipality, leads the municipal government and its administration and conducts the financial administration of the municipality. The Mayor exercises all competencies not explicitly assigned to the Municipal Assembly or its committees. Mayor has for dutie to executes the Municipal Assembly acts, appoints and dismisses his deputies, appoints and dismiss his advisors who assist him in discharging his duties organizes the work and directs the policy of the municipality. The Mayor proposes municipal regulations and other acts for the approval of Municipal Assembly, proposes municipal development, regulatory and investments plans; proposes the annual budget for the approval of the Municipal Assembly and executes the budget adopted. The Mayor reports before the Municipal Assembly on the economic-financial situation and the implementation of the investment plans of the Municipality at least once every six months or as often as required by the Municipal Assembly, and may request the Municipal Assembly only once to review a municipal act when he deems the act to violate the applicable legislation and/or the interests of communities. The Mayor shall consult the Deputy Mayor for Communities about the matters related to non-majority communities; and other activities assigned to him/her by the statute. (Law No. 03/L-04 article 58). Municipal acts approved by the Municipal Assemblies of the Republic of Kosovo have regulated many fields, but the most important ones that we can mention are: adoption of urban regulation plans, acts in the environment field, adoption of the decisions regarding the use of municipal immovable property, decisions for the names of streets, adoption of the acts in the area of public services, regulation of the internal organization of the administration, acts that regulate generation of the municipal revenues, municipal safety mechanisms, etc.( MLGA Monitoring Report of the Republic of Kosovo Municipalities January-December 2012, p.7). With the strengthening of Mayor's role, local self-government in Kosovo has remained without control mechanisms, since municipal assemblies in most of the cases are composed of a majority which comes from the party and coalitions that have won the elections, but even in case of the contrary it is impossible to exercise any control over the Mayor. The lack of institutional 
tradition has left room for party mechanisms to interfere in the work of municipalities. Mayor of municipality in most of the cases has two addresses of accountability, one to the entity that has nominated him and the other to the citizens as stipulated in the law. However, one of the accountability addresses, i.e., to citizens, is very weak because most of the ideas expressed by citizens in public debates have never been followed up, which means that Mayors organize such public meetings just to meet a formal requirement. The real address of accountability in practice is the party which he or she represents and which is turned into an address of obligations that Mayor has to fulfil during his/her mandate. This is explained by the fact that in many municipalities Mayors are usually presidents of party branches. (Tahiri,B.,2012, p.10).

\subsubsection{Control carried out by the Mayor of municipality in relation to municipal directorates}

Mayor, pursuant with the provisions of the Rules and the Statute of the Municipality, is responsible for: call the meetings of the Assembly, their presiding and the progress of the Assembly activity; perform the function of Chairman of the Policy and Finance Committee and has a casting vote in case of vote equality pro and against; presiding the meeting of the Board of Directors; appoint of the directors to assist the President in performing his/her duties, except the Head of the Directorate of Administration and Personnel; appoint the member of the Board of Directors, which shall exercise the responsibilities of the President in his absence; take care to implement the provisions of the Regulation on self-government of municipalities in Kosovo and other legal provisions dealing with the responsibilities of municipalities; monitor the overall financial management of the municipality and the implementation of decisions taken by the Municipal Assembly; determine the establishment, organization and activity of the municipal administration, and the constituting of institutions and enterprises; make the assignment or temporary separation and coordination of duties and responsibilities between departments, as appropriate, taking into account the particular project area or etc.(Municipal Statute of Pristina article 51).

The municipal administration shall be organized into directorates. Each municipal directorate shall be managed by a director who is employed and dismissed by the Mayor. The directors shall manage their directorates in accordance with the strategic and political strategies of Mayor and in accordance with Laws and municipal applicable regulations. Directors shall regularly report to the Mayor for the matters that are under their responsibility and shall provide him/her all necessary information and reports for the decision-making process. (Law No. 03/L-040 article 62). The municipal administration shall have a Head of Personnel. The Mayor shall announce the post, recruitment and dismissal of the Head of Personnel in accordance with the applicable law on civil service. If the position of the Head of Personnel becomes vacant, the Mayor shall appoint in an acting capacity a senior member of the municipal civil service.(Law No. 03/L-040 article 66). As mentioned above, Board of Directors consists of Directors appointed by the Mayor, the Head of the Directorate of Administration and Personnel and the Director of the Office of Communities. each member of the Board of Directors: a) regularly reports to the President on matters that are their responsibility; b) assists the President, the Municipal Assembly and its Committees by providing all the necessary information and reports for the decision-making process; c) implement all regulations and decisions of the Municipal Assembly and the laws passed by the Assembly of Kosovo; d) prepare the activity program and presents periodic reports of the activity to his department; $f$ ) is responsible for the daily management and control of directorate; d) prepares and presents periodic development plans in their area of responsibility and monitoring of these plans; $e$ ) responds effectively to any complaint relating to its sphere of responsibility; f) participates and contributes to the activity of the Municipal Assembly, its Committees and the activity of the Board of Directors; $g$ ) ensures that it shall provide fair and equitable access 0 for those public services that are in its responsibility; j) it has met all the tasks and orders assigned in appropriate way.(Municipal Statute of Pristina Article 59).

\subsection{Reporting of the Mayor in the Municipal Assembly}

The Mayor has responsibility to report before the Municipal Assembly on the economic-financial situation and the implementation of the investment plans of the Municipality at least once every six months or as often as required by the Municipal Assembly. ( (Law No. 03/L-040 article 58 drops J ). However, this law does not clarify whether the reports presented will undergo a voting process, and the consequences of their disapproval. In practice, it is has been noted that the mayors present written reports to the municipal assemblies, the approval of which is an internal issue of municipalities and has no legal consequences. Other forms of reporting are verbal ones, where the assembly membership ask direct questions or in writing, depending on the nature of the case. Such practices have been noted as a good opportunity of 
executive accountability before the Assembly and provision of answers to many questions. Some municipal assemblies prioritize direct questioning of the municipal executive by regulating this segment with a priority on the agenda. In order to successfully implement this type of control, is needed the presence of mayors, municipal deputy-mayors and municipal directors in the assembly meetings. It is noted that the mayors did not always pay attention to their presence at the meetings of the Municipal Assembly, as this obligation, to most cases bear the deputy mayors and directors of departments. During this period, the presence of mayors is not observed to three municipalities. Municipalities four, mayors have not always been present to assembly meetings, while in other municipalities their attendance has been present. (MLGA Report on functioning of the Municipal Assemblies of the Republic of Kosovo January -June 2013, p.12). For example, during the sixmonth period of 2014 from the collected data for the reporting of Mayors in Municipal Assemblies, it appears that in 38 municipalities there are 37 reports, but there are 6 municipalities in which their Mayors have not reported to the Municipal Assembly.( MLGA Six-moth report of functioning of the Municipal Assemblies of Republic of Kosovo 2014, p.10). From the collected data for the reporting of Mayors in municipal Assemblies during 2014, it appears that in 38 municipalities ther have been 88 rapors. Mayors 6 municipalities have not fulfilled the obligation to report to the Municipal Assembly at least twice year.( MLGA report of functioning of the Municipal Assemblies of Republic of Kosovo, January-December 2014, p.13).

Although, regarding the obligation of mayors to submit quarterly budget report, this is done in all municipalities. Although Law No. 03/L-048 on Public Financial Management and Accountability has not called for the voting (approval) of financial reports from the Municipal Assemblies, the adoption of these reports is the practice of most municipalities. While municipalities that do not practice voting of the executive financial reports are: Kaçanik, Partesh, Deçan, Graqanica, Gjakova, Mitrovica, Rahovec and Suhareka.(MLGA Report on Functioning of the Municipal Assemblies of the Republic of Kosovo January - June 2013, p.13) .

\subsection{Supervisory Authorities for the local government}

The ministry responsible for the local government is the supervisory authority unless; the responsibility for the review of municipalities is assigned by law to the responsible ministry or institution with respect to a specific field. The review of the delegated competencies is exercised by the body of central government which has delegated them. Referring law on Local Self-Government article 77 provides that Municipal and supervisory authorities are obliged to cooperate with each other in the process of administrative review. All measures of review shall be taken by review authorities through the relevant legal acts. Such acts shall state the legal basis and explain the reasons for the application of a certain review measure.(Law No. 03/L-040 articles 76 and 77).The supervisory authority has the right to receive and obtain full information on all matters concerned, including the right to visit the municipal offices and municipal facilities and to request access to municipal documents. The Mayor shall be responsible for making this information available to the supervisory body. During such visits, the representatives of the supervisory body shall not give direct instructions to the staff of the local self-government bodies. The ministry responsible for the local government has the right to be regularly informed by the municipalities on the areas of which the ministry it is not the supervisory authority.(Law No. 03/L-040 article 78 ). In order to facilitate the supervision and create a more efficient system in carrying out the review of legality of municipal acts, ministerial committees were established according to specific fields.(MLGA Report on functioning of municipalities of the Republic of Kosovo 2013, p. 24). The possibility of supervision of local self-government bodies by the supervisory authority is the raised issue on constitutional level. Although municipalities have a high degree of local self-government, the central authorities have the jurisdiction and control of their supervision in order to ensure the legality of municipal acts. In compliance with the legal framework applied in Kosovo are defined the mechanisms of administrative review and oversight of the law enforcement from central level. Supervision of municipal authority activities should be in accordance with the law and the European Charter of Local Self-Government which doesn't allow to violate the autonomy of local government in exercising its supervision.( MLGA Administration Monitoring report of the Republic of Kosovo Municipalities January-December 2012, p.57). Monitoring of the activities and supervision has be in proportion with the legal purpose to be achieved. The monitoring activity and supervision should have as little impact as possible on the interests of municipalities and to minimize the time commitment of the officials of the municipality in this process. (MLGA Administrative Instruction No.2008/4 article 4) Monitoring and supervision of municipalities in e exercising of their own competencies shall be limited only with monitoring and supervison of legality, it means (Ibid article 6). The review conducted by the supervisory authority to ensure that municipal acts have been issued in conformity with applicable legal provisions and that the issuing body has not acted in excess of its legally recognized mandate.( Law No. 03/L-040 article 3). 
Monitoring and supervision of municipalities in exercising of delegated authority should include, supervision of lawfulness and supervision of suitable actions,( MLGA Administrative Instruction No.2008/4 article 6), but also effectiveness and efficiency of activities,which also extends to the capabilities of officials who carry out these affairs.

In short, this type of supervision is similar to the hierarchical control that exists within the government administration.(Ivanisevic',Kopric',Omejec \& Simovic,p.190).

Review of expediency shall mean the review conducted by the supervisory authority to ensure that delegated competencies have been executed in compliance with the rules, criteria and standards determined by the central government and if the measures taken by municipality were appropriate to achieve the results determined by the Government of Republic of Kosovo.(Law No. 03/L-040 article 3 ). Also, article 8 of The European Charter of Local Self-Government (KEVL) provides that Administrative supervision of local authorities' activities. Referring to article 8 Paragraph 2 provides that any administrative supervision of the activities of the local authorities shall normally aim only at ensuring compliance with the law and with constitutional principles. Administrative supervision may however be exercised with regard to expediency by higher-level authorities in respect of tasks the execution of which is delegated to local authorities.(The European Charter of Local Self-Government art.8 paragraph 2). However, it is important that the local government body, when possible, to be allowed to take into account local circumstances in exercising delegated powers, providing that return to this delegation does not excessively violate the sphere of authority of the independence of local authority From the other side, it is recognized that in respect of certain functions, such as issuing of identity documents, the need for uniform regulations may leave no scope for local discretion.(European Charter of Local Self-Government and explanatory report article 4 paragraph 5). Also, KEVL provides that Administrative supervision of local authorities shall be exercised in such a way as to ensure that the intervention of the controlling authority is kept in proportion to the importance of the interest which it is intended to protect.(The European Charter of Local Self-Government article 8 paragraph 3). As mentioned above, State bodies shall supervise the lawfulness of the work of municipal bodies. In matters vested in municipalities by the state, state bodies shall also supervise the appropriateness and expertise of their work. The state supervision of the work of a local community body shall be exercised by the government and ministries. (Republic of Slovenia The law on Local Self-Government article 88). Ministry of Local Government Administration (MLGA) has developed an advanced system of monitoring supported in two main ways: through monitoring with direct participation in municipalities and through electronical monitoring realized in several different forms. Having into consideration the advantages of the information technology and for the purpose of decreasing the financial cost, MLGA has installed a special program to enable the supervision from distance through telepresence.( MLGA Organization and functioning of Local Self-Government in Kosovo, 2013, p.58).

\subsubsection{Review of the Legality of Municipal Acts}

The Municipal Assembly may adopt acts within their areas of its competences. Acts of the Municipal Assembly shall be effective in the territory of the Municipality enacting the act. These acts shall include: Statute of the Municipality; rules of Procedure; Municipal regulations; and any other acts necessary or proper for efficient operation of the Municipality. (Law No. 03/L-040 article 12). In the context of state supervision, a distinction is made between two kinds of supervision: legal supervision and functional supervision. As far as the municipalities act within their own sphere of activity, they are subject to legal supervision. (Jürgen Harbich, 4/2009, p.56). Supervision over the legality of general self-government acts of local representative bodies is carried out by all central government administration bodies, each within its scope of activities.(Ivanisevic',Kopric', Omejec \& Simovic, p. 189).

For example, in the Republic of Slovenia Supervision of the legal implementation of general acts and individual municipal acts relating to matters that fall under their jurisdiction shall be carried out by the ministries, each in the area of their competence. For the purpose of supervising the legal operation of municipal bodies, the ministries must ensure suitable cooperation, the mutual supply of information and professional assistance for municipal bodies. Ministries must warn the municipal body which they believe has issued an act which does not comply with the Constitution and the law, and shall propose suitable solutions. In addition, ministries must warn competent municipal bodies if they determine that the municipal administration is not acting in accordance with the law or other regulations, and shall propose suitable measures. At the proposal of a ministry, the Government shall propose that the Constitutional Court withhold the execution of a municipal general act which the ministry or the Government believes may cause major disturbances in the implementation of municipal tasks, have harmful effects on the health or life of people, or cause major economic damage, or whose 
implementation would represent a violation of the Constitution or other legally guaranteed rights and freedoms of citizens. (Republic of Slovenia The law on local self-government Article 88a).

In Republic of Kosovo the government's main mechanism for the supervision of the constitutionality and lawfulness is the right of the supervisory authority for the administrative review for lawfulness of the municipalities' bylaws. (MLGA Report on functioning of the Municipal Assemblies of the Republic of Kosovo January - June 2013, p.27).

The ministry responsible for the local government is the supervisory authority unless; the responsibility for the review of municipalities is assigned by law to the responsible ministry or institution with respect to a specific field. The review of the delegated competencies is exercised by the body of central government which has delegated them. (Law No. 03/L-040 article 76).

Monitoring and supervising authority must be careful when monitoring and supervising activities that should have as little impact as possible on the interests of municipalities and to minimize the time commitment of municipal officials this process.(MLGA Administrative Instruction No.2008/4 article 4).

The administrative review of acts of municipalities by the central authorities in the area of their own competencies shall be limited to ensuring compatibility with the Constitution of the Republic of Kosovo and the law.(The Constitution of Kosovo article 124$)$. Administrative review of municipal functioning in delegated competences is subject to legality review and suitability of actions. (MLGA Progress report on implementation of decentralization, 2012, p. 15). The Mayor of a municipality shall forward to the supervisory authority by the 10 th of each month, a list of all acts adopted by the Mayor and the Assembly in the previous month. Law No. 03/L-040 article 80). According to LLSG the following acts are subject to procedure of mandatory legality review of legality: General acts adopted by municipal assemblies; Decisions related to joint activities of partnership and cooperation; Acts adopted within implementation framework of delegated competences. (MLGA Progress Report on implementation of decentralization 2012, p. 15). For every registered act in protocol office, the Ministry of Local Government Administration (MLGA) must declare within 15 days from the date of registration the legality of the acty.In case undeclared by the Ministry of Local Government Administration (MLGA), the act is considered to be in accordance with the law in force.( MLGA Administrative Instruction No.2008/4 article 11).

The administrative review of the municipalities has the following objectives: to strengthen the ability of the local selfgovernment bodies to meet their responsibilities through advice, support, and assistance; to ensure the lawfulness of the activities of local self-government bodies; and to ensure that the rights and interest of citizens are respected. (Law No. 03/L-040 article 74). MLGA has identified the MA acts through monitoring of meetings. Moreover, MLGA has evaluated the acts which were not under the competence of other authorities of the central level from the legal perspective. The acts for which MLGA was not competent were submitted to the responsible ministries, respectively ministerial committees. In this regard, a number of legal violations were identified during the issuance of acts from the MAs. (MLGA Report on functioning of municipalities of the Republic of Kosovo 2013, p.24)The data on the process of review of the legality of municipal acts are presented below for three years: Ministry of Local Government Administration, from years 2012 to 2014 has identified violations of the law based on the assessment of the legality of acts of municipalities, MLGA has found this situation regarding the legality of acts of municipalities: In year 2012 the acts that Ministry of Local Government Administration received for reviewing of legality and according to the estimations given by inter-ministerial commissions established especially for this purpose have been reviewed a total of 42 acts of unlawful content. Municipal review level of the acts is $50 \%$ respectively 20 acts have gone back for review while 22 remain unexamined. (MLGA Monitoring report of the Republic of Kosovo Municipalities January-December 2012, p. 8. ). Also, in the year 2013 Municipalities have been active in issuing sub-legal acts, with 1107 decisions and 142 regulations were adopted in the period from January to December 2013. (MLGA Report on functioning of municipalities of the Republic of Kosovo 2013, p.15). The total number of unlawful acts issued by Municipal Assemblies is 59. Out of this number, municipalities have revised 39 acts (or $66 \%$ ). 27 acts (or 69\%) were harmonized in accordance with the recommendations of the supervisory organ. 12 acts (or 30\%) were not harmonized in accordance with the demands of the supervisory body. 20 acts (or 33\%) were not reviewed at all. (MLGA Report on functioning of municipalities of the Republic of Kosovo 2013, p.8. Similar to this, the Municipal Assemblies of the Republic of Kosovo in the first six months of 2014 held 25 meetings in total. From them 216 meetings were monitored, or $96 \%$ in percentage of held meetings. Regarding the acts 1,081, are approved in total, of which64 confirmations are given legality by the Ministry of Local Government Administration, and are recorded 29 violations of the bylaws of the municipalities, of which 18 were reviewed and 1 is still non-harmonized with the applicable legislation. In total they addressed 253 acts of municipalities for review and evaluation of legality to Ministries and Cectoral Committees for Assessment of the legality of 
acts of municipalities as required by the decision of the Government of the Republic of Kosovo.(Report for the work the Ministry of Local Government Administration) In January-December 2014, the municipal assemblies have approved a total of 2,030 acts, of which 6 municipal Statutes, regulations 148 and 1876 decisions. It is apparent that municipalities have been very active in issuing of legal bylaw regulations.(Report on functioning of municipalities of the Republic of Kosovo January-December 2014, p. 14). Ministry of Local Government, in assessing the legality of acts has found that violations have made a total of 28 municipalities. Number of illegal acts is 52 , of which 35 acts are revised and harmonized with the law, 12 acts were not reviewed by the request for reconsideration, and 5 are not harmonized acts upon reconsideration in the Assembly.(Ibid, p.20).

\subsection{Inspection}

Some public services are offered from the central authorities while some are offered by the local level. Municipality inspects provision of services for some services, such as: market inspection, inspection of construction, sanitary inspection etc. for the purpose of the protection of legality. Together with some competences the inspection services were also centralized. The central institutions also organize the services of inspection, such as: inspection of work, environment, education, health etc. The own competences of the municipalities, such as: water supply and canalization, fire extinguishing, regional waste landfills are offered by the publicly owned enterprises, agencies or units that are under management of the central level.( MLGA Organization and functioning of Local Self-Government in Kosovo, 2013 p.56 ).

\subsection{Audit and Internal control in municipalities}

Procedures of good governance are intended to confirm that management implemented a range of internal controls to ensure that financial systems operate as intended. It is important that they include the proper reporting to Management enabling an effective and timely response to the operating and financial identified challenges. Review made to higher management controls implemented in the main municipal financial system highlight a good or a poor control over expenditures and revenues. (Audit Report of the Municipality of Peja, 2014,p.15).

Every public institution is obliged to audit the public money.(MLGA Organization and functioning of Local Self-Government in Kosovo, 2013, p. 56). It helps an organization to accomplish its objectives by providing a systematic, disciplined approach to evaluate and improve the effectiveness of risk management, control, and governance processes. (Law No. 03/L-128 article 3). The audit of public finances is another very important process for ensuring transparency in the spending of public funds in accordance with the budget and procurement plans. Municipalities in Kosovo have established specific structures of auditing to make independent control and internal audit of the finances, but still some municipalities are not stable in this segment.( MLGA Report on capacity assessment of municipalities 2012,p.42).

Law No. 03/L-040 on Local self Government provides that the Municipal Assemblies shall establish and maintain the Committee on Policy and Finance and the Committee on Communities as permanent committees. The Policy and Finance Committee shall be responsible to review all the policy, fiscal and financial documents, plans, and initiatives including strategic planning documents, the annual Medium Term Budget Framework, the annual procurement plan, the annual regulation on taxes, fees and charges, the annual internal audit work plan, the annual medium term budget and any changes to the budget during a fiscal year as well as reports from the Mayor and submit recommendations for action to the Municipal Assembly. ( Law No. 03/L-040 articles 51 and 52). Their role is expressed in the preliminary discussion of all issues that are foreseen to be dicussed in the Municipal Assembly, and for this reason it is considered as a prevention mechanism.(MLGA Organization and functioning of Local Self-Government in Kosovo, 2013, p.57). Apart from internal control, each municipality is also undergoing external financial audit by the Office of the External Auditor. The principle of accountability, efficiency and transparency in public money spending derives from the Constitution and Laws of the Republic of Kosovo. The public institutions, both local and central are obliged to respect these principles whenever spending public money. Audit financial reports of the financial statement of municipalities prepared by the Office of the Auditor General are one of the supervisory and measuring mechanisms of the public money spent by the local government institutions. In addition to auditing, each year OAG provides concrete recommendations to the municipalities to ensure that recommendations given by audit are properly addressed. According to the applicable law, the Auditor General shall annually conduct a Regularity Audit of the Kosovo Consolidated Budget, as well as the municipalities of the Republic of Kosovo. OAG currently plays two 
roles: monitoring and giving recommendations regarding better management of public finances.( MLGA Progress report on implementation of decentralization, 2012, p.45). Poor accountability requirements and poor quality financial reporting reduced the efficiency of financial and operational management in the Municipality and may result in poor value for money and/or possible financial loss. Lack of effective Audit Committee reduces the focus and impact of internal audit activity and reduces the assurance that the internal audit provides to the Management. The Mayor should review current governance arrangements and related reporting requirements. The Mayor should strengthen controls on procurement planning and implementation securing that open procedures are used for expenditures of the same nature to achieve the highest value for money paid. (Audit Report of the Municipality of Peja, 2014, p.16).

\section{Conclusion}

Local governance in Kosovo after the war in 1999 faced many challenges since the efforts for constituting of local administration by international institutions, the transfer of responsibilities from international to local, local government reforms, constituting of new municipalities and decentralization. One of the challenges in the past was the three northern municipalities of Kosovo community with Serb majority about their not readiness for cooperation with the Central Institutions of Kosovo, a challenge that will continue for a certain period, which requires more activity and commitment from the central level as well as from International and local political structures. Local governance in Kosovo as other transition countries, which claim to integrate in the EU, are facing the challenge to achieve the provision of services under the highest standards of citizens.

The effort of municipalities to meet the needs and expectations of citizens and local organizations and to attract more investment as indoor and outdoor in their municipalities. However, the staff of the municipality to provide the best in service by providing the highest standards and to satisfy the expectations of citizens may only be successful, if the staff has been given autonomy and responsibility at work. Central Government of Kosovo should be committed to have local government with positive performance, have the ability to manage the high costs and provide services with the highest standards and be close to the citizen of their municipality.

Ministry of Local Government, is the responsible authority for the supervision of municipalities of Kosovo and assessment of the legality of municipal acts. This ministry has constantly had a surveillance about the identified legal violations of municipal bylaws.

- In the future all municipalities shall require to approve the municipality acts in accordance with the applicable legislation in Kosovo.

- Obligate the municipalities in case of unlawful adoption of the act to review the same and all municipal acts to harmonize with the applicable legislation in Kosovo in case of lack of compliance to address them to the Constitutional Court.

- All Mayors should report to the Municipal Assembly and meet their legal obligations and be transparent to the Municipal Assembly and the citizens.

- Supervision and control of local government has an impact in increasing of accountability, efficiency, and accountability transparencies local government and providing of high quality services for the citizens.

\section{Literature}

3. Dobjani Ermir, Administrative Law 1, Tiranë: SHBLU, 2004

4. Jürgen Harbich, State Supervision of Local Government Authorities, Uprava, 58 letnik VII, 4/2009

5. Polozhani, Bajram \& Dobjani, Ermir \& Stavileci, Esat \& Salihu, Lazim: "Comparative aspect", 2010

6. Sokoli Argur, Control of the work that the administration and its political responsibility Pristina, October 2009

7. Stjepan Ivanisevic', Ivan Kopric', Jasna Omejec \& Jure Simovic, Local Government in Croatia, Local Governments in Central and Eastern Europe, Chapter 5

8. Tahiri Besnik 'The Municipal Mayor a representative or a dominant authority?' A contribution to strengthening institutional accountability and transparency at the local level - Kosovo Case November, 2012; See the web site: 
http://www.fes-prishtina.org/wb/media/Publications/2012/The\%20Municipal\%20Mayor\%20-

\%20A\%20Representative\%200R\%20A\%20Dominant\%20Authority.pdf; downloaded date 20.08.2015

9. Constitution of the Republic of Kosovo ( with amendments i-xxiii ) this edition includes text of the Constitution of the Republic of Kosovo (adopted on 9 april 2008) with amendments $\mathrm{i}$ - xxii (official gazette of Republic of Kosovo no.25, date 7 September 2012) end amendment xxiii (Official Gazette of Republic of Kosovo no.7, date 26 march 2013)

10. Regulation No. 2001/9 a Constitutional Framework for provisional Self-Government in Kosovo

11. Council of Europe, European Charter of Local Self-Government, Strasbourg, 1985

12. Law N0. 03/L-040 on local self government Official Gazette of the Republic of Kosova / Pristina: Year III / No. 28 / 04 June 2008

13. Law No.03/L -189 on the state Administration of the Republic of Kosovo Official gazette of the Republic of Kosova / Pristina: year v / no. 82 / 21 October 2010

14. Law No. 03/L-128 on Internal Audit of the Republic of Kosovo

15. Republic of Slovenia The law on local self-government (Official Gazette of the Republic of Slovenia, no. 72/93, 57/94, 14/95, 26/97, 70/97, 10/98, 74/98, 70/00 Decision of the Constitutional Court: Official Gazette of the Republic of Slovenia, no.6/94, 45/94, 20/95, 73/95, 9/96, 39/96, 44/96, 59/99)

16. Resolution 1244 (1999) Adopted by the Security Council at its 4011th meeting, on 10 June 19991

17. Regulation No. 1999/1 UNMIK/Reg/1999/1 25 July 1999 on the authority of the interim administration in Kosovo

18. Regulation No. 1999/14 UNMIK/Reg/1999/14 21 October 1999 on the appointment OF Regional and Municipal Administrators

19. Administrative Direction No: for altering of Adminsitrative Instruction No; $200 / 5$ for application of responsibilities of Minsityry of Administration of Local Public Governence related to monitoring and supervision of Muncipalities.

20. Municipality Statute of Prishtina, approved by the Assembly of Prishtina Municipality, 01. Nr. 110-391, dated February 2, 2010.

21. Republic of Kosovo Ministry of Administration of Local Government Progress, Report on implementation of decentralization in the Republic of Kosovo , Pristina, August 2012

22. Republic of Kosovo, Ministry of Administration of Public Governance, Report of Evaluation of Municipal Capacities, Prishtina, March, 2012.

23. Republic of Kosovo Ministry of Local Government Administration Monitoring report of the Republic of Kosovo Municipalities January-December 2012, Pristina 2013

24. Republic of Kosovo Ministry of Local Government Administration Report on Functioning of the Municipal Assemblies of the Republic of Kosovo January - June 2013, Pristina 2013

25. Republic of Kosovo Ministry of Local Government Administration, Organization and functioning of Local SelfGovernment in Kosovo, Pristina, August 2013,

26. Republic of Kosovo Ministry of Local Government Administration Report on functioning of municipalities of the Republic of Kosovo January-December 2013, Pristine, 2014

27. Republic of Kosovo Ministry of Local Government Administration Municipal performance Report 2014, Pristina, January 2015

28. Republic of Kosovo Ministry of Local Government Administration Monitoring report of work of Ministry of Local Administration Governance January-June, 2014

29. Republic of Kosovo, Ministry o Administration of Local Governance, six-moth report of functioning of the Municipal Assemblies of Republic of Kosovo 2014.

30. Republic of Kosovo, Ministry o Administration of Local Governance, six-moth report of functioning of the Municipal Assemblies of Republic of Kosovo, January-December 2014 Prishtina, April 2015

31. Office of the Auditor General Audit Report on the financial Statements of the Municipality of Peja for the year 31 December 2014 Document No: 22.6.1-2014-08, Prishtina, June 2015 